\title{
UJI RESISTEN INSEKTISIDA MALATHION TERHADAP NYAMUK AEDES AEGYPTI DI KOTA TANGERANG
}

\author{
*Cecep Dani Sucipto, *Kadar Kuswandi, *Budi Siswanto
}

\begin{abstract}
Abstrak
Penggunaan insektisida untuk pengendalian vektor dalam skala luas secara terus menerus dalam jangka waktu cukup lama dan frekuensi tinggi dapat menimbulkan terjadinya penurunan kerentanan pada nyamuk sasaran. Mulai tahun 2003 malathion digunakan sebagai pengganti insektida peritroid dengan alasan insektisida tersebut berbeda golongan. Tujuan penelitian ini adalah untuk mengetahui status kerentanan nyamuk $A e$. aegypti di Kecamatan Neglasari kota Tangerang terhadap insektisida jenis malathion. Penelitian dilakukan secara eksperimen yaitu menentukan status kerentanan nyamuk $A e$. aegypti dengan uji susceptibity terhadap insektisida malathion. Lokasi pengambilan sampel nyamuk Ae. aegypti dalam penelitian ini dibagi menjadi 2 kelompok, yaitu kelompok perlakuan yang meliputi kota Tangerang dimana wilayah tersebut telah dilakukan penyemprotan insektisida organofosfat dalam pemberantasan nyamuk DBD, dan kelompok pembanding nyamuk Ae aegypti dari Laboratorium Parasitologi FK UGM Yogyakarta yang belum terpapar insektisida. Berdasarkan hasil penelitian, maka dapat disimpulkan sebagai berikut nyamuk Ae. aegypti belum mengalami resistensi di kelurahan Neglasari masih rentan terhadap insektisida malathion. Disarankan Perlu dilakukan monitoring terhadap penggunaan insektisida malathion, dengan memantau efektivitasnya terhadap nyamuk Ae. aegypti di lokasi tersebut, Malathion perlu di ganti dengan jenis lain dalam aplikasi thermal fogging, karena nyamuk Ae. aegypti di lokasi tersebut sudah resiten, Sebelum dilakukan thermal fogging dengan insektisida, sebaiknya dilakukan uji hayati nyamuk Ae. aegypti di lokasi tersebut terhadap insektisida yang akan digunakan, Penelitian lebih lanjut terhadap kelurahan yang belum diteliti, untuk memperoleh gambaran tentang status kerentanan/resistensi secara menyeluruh.
\end{abstract}

\section{Kata Kunci: Uji Resistensi, Malathion, Aedes aegypti}

*Poltekkes Kemenkes Banten 


\section{Pendahuluan}

Penyakit Demam Berdarah Dengue (DBD) di Indonesia merupakan salah satu penyakit endemik, dan telah menjadi permasalahan kesehatan serius yang menimbulkan banyak korban kematian. Hal ini dikarenakan penyakit tersebut penyebarannya sangat cepat dan sering menimbulkan kejadian luar biasa (KLB), sehingga menimbulkan kesakitan dan kematian yang tinggi. Penyakit DBD disebabkan oleh virus dengue dan ditularkan oleh nyamuk Aedes aegypti sebagai vektor utama dan Aedes albopictus sebagai vektor sekunder.

Fenomena pergeseran kejadian luar biasa (KLB) DBD di Indonesia, sebelumnya pada tahun 1970-1990 KLB terjadi secara berkala 4-6 tahun telah mengalami pergeseran sejak tahun 2005 menjadi 3-4 tahun, bahkan di beberapa kota KLB terjadi dalam jangka waktu 1-2 tahun (Kusriastuti, 2005). Selama tahun 2008 jumlah penderita DBD di Banten mencapai 802 orang. Sedangkan pada tahun 2009 sampai bulan Juli kasus DBD mencapai 800 kasus dan 40 orang meninggal dunia atau telah mengalami out break.

Pada masa KLB dan dalam musim penularan penyakit DBD, penggunaan insektisida tidak dapat dihindarkan. Penggunaan insektisida untuk pengendalian vektor dalam skala luas secara terus menerus dalam jangka waktu cukup lama dan frekuensi tinggi dapat menimbulkan terjadinya penurunan kerentanan pada nyamuk sasaran (WHO, 1995; Georghiou \& Mellon, 1983). Hal ini terbukti adanya kecenderungan resistensi nyamuk terhadap insektisida di beberapa daerah di Indonesia, salah satu contohnya penelitian yang dilakukan di Kota Bandung terhadap jenis insektisida sipermetrin telah mengalami resistensi (Dindin, 2008).

Sejak tahun 1991 sampai dengan sekarang Dinas Kesehatan Kota Tangerang menggunakan malation dalam program pengendalian DBD. Mulai tahun 2003 sipermetrin digunakan sebagai insektida pendamping malation dengan alasan insektisida tersebut 
berbeda golongan, dimana malation termasuk golongan organofosfat sedangkan sipermetrin (Cynop) golongan piretroid.

Berdasarkan uraian diatas, kami tertarik untuk mengetahui tingkat resistensi nyamuk Aedes aegypti terhadap insektisida malation yang digunakan dalam program pengendalian DBD di Kota Tangerang.

\section{Metode Penelitian}

Penelitian dilakukan secara observasional yaitu menentukan status kerentanan nyamuk $A e$. aegypti dengan biossay test metode discriminating dose dan untuk mengetahui mekanisme restensi $A e$. aegypti dengan biochemis test $\mathrm{di}$ laboratorium.

Lokasi pengambilan sampel nyamuk Ae. aegypti dalam penelitian ini meliputi kota Tangerang dimana wilayah tersebut telah dilakukan penyemprotan insektisida organofosfat dalam pemberantasan nyamuk DBD, dan kelompok pembanding nyamuk Ae. aegypti dari Lab Parasitologi UGM Yogyakarta.

Populasi penelitian adalah nyamuk Ae. aegypti di kota Tangerang. Unit sampel adalah nyamuk Ae. aegypti dari lokasi endemis di Kelurahan Karangsari, Kecamatan Neglasari kota Tangerang.

Status kerentanan nyamuk $A e$. aegypti terhadap insektisida sipermetrin dengan metode susceptibility test kit yang dilengkapi dengan impregnated paper. Kriteria kerentanan nyamuk ditetapkan berdasarkan persentase angka kematian nyamuk, jika kematian sebesar 99 - 100\% populasi disebut peka/rentan, kematian $80-98 \%$ disebut toleran dan kematian $<80 \%$ disebut resisten.

\section{Hasil}

\section{a. Uji susceptibity Ae. aegypti terhadap malation}

Hasil pengujian yang dilakukan di laboratorium entomologi Universitas Gadjah Mada pada larva nyamuk yang diambil secara proposional di kelurahan 
Neglasari memperlihat hasil sebagai berikut:

Tabel 1

Hasil Uji Susceptibity Larva Ae. aegypti Terhadap Malathion di Kota Tangerang Tahun 2014

\begin{tabular}{cccc}
\hline $\begin{array}{c}\text { Waktu } \\
\text { Pengamatan } \\
\text { (Menit) }\end{array}$ & \multicolumn{3}{c}{$\begin{array}{c}\text { Angka } \\
\text { Kematian } \\
\text { Larva }\end{array}$} \\
\cline { 2 - 4 } I & II & III \\
\hline 15 & 0 & 0 & 0 \\
\hline 30 & 0 & 0 & 0 \\
\hline 45 & 0 & 0 & 0 \\
\hline 60 & 0 & 2 & 1 \\
\hline 75 & 3 & 4 & 6 \\
\hline 90 & 7 & 12 & 10 \\
\hline 105 & 15 & 16 & 14 \\
\hline 120 & 20 & 21 & 17
\end{tabular}

Keterangan:

I : Kematian larva pada perlakuan pada tabung pertama

II : Kematian larva pada perlakuan pada tabung kedua

III : Kematian larva pada perlakuan pada tabung ketiga

Berdasarkan tabel di atas Kematian larva pada tabung kedua yang paling banyak yaitu 21 ekor larva, sedangkan Kematian larva pada tabung ketiga sebanyak 17 ekor. Kematian larva terjadi pada 60 menit setelah di kontakan dengan impregnated paper yang berbahan aktif malathion.

Uji susceptibity dilakukan terhadap populasi nyamuk jentik $A e$. aegypti terhadap insektisida malation, dari masing-masing kelurahan diambil secara random sebanyak 75 ekor yang tersebar di wilayah kecamatan Neglasari Kota Tangerang.

\section{Pembahasan}

Berdasarkan tabel di atas Kematian larva pada tabung kedua yang paling banyak yaitu 21 ekor larva, sedangkan Kematian larva pada tabung ketiga sebanyak 17 ekor. Kematian larva terjadi pada 60 menit setelah di kontakan dengan impregnated paper yang berbahan aktif malathion.

Kematian larva Ae. aegypti rata-rata pada tiga tabung uji susceptibity 19,33 ekor, dengan patokan Kriteria $<80 \%$ adalah resisten/kebal, kemudian 80-98\% adalah toleran dan kematian 90$100 \%$ adalah rentan. Berdasarkan 
perhitungan prosentase kematian mencapai 77,32 \% , artinya larva Ae. Aegypti yang ada di Neglasari telah mengalami resistensi $(<80 \%)$.

Nyamuk Ae. aegypti yang berasal dari kelurahan Neglasari telah mengalami resistensi terhadap insektisida malation. Hal ini di perkirakan berhubungan erat dengan tingginya pemakaian insektisida jenis malathion secara terus menerus seirin jumlah kasus yang selalu ada setip tahunnya. Kondisi di atas di dukung oleh teori penyebab resistensi nyamuk vektor akibat paparan insektisida pada operasional pengendalian kepadatan vektor dengan penggunaan insektisida malation di kota Tangerang. Penggunaan insektisida secara terusmenerus cenderung mempercepet proses terjadinya resistensi serangga. Kerentanan serangga tidak hanya dipengaruhi oleh lama dan frekuensi paparan insektisida saja, tetapi juga frekuensi gen yang ada apaakah dominan heterozygote atau homozygote pada populasi serangga (Hemingway et al., 1986a). Faktor genetik lainnya adalah bagiamana interaksi antar gen atau gen-gen pembawa sifat tersebut. Adanya seleksi dari insektisida sebelumnya dapat mempengaruhi proses berkembanganya resistensi.

Hal ini juga di perkuat oleh hasil penelitian dindin wahyudin di Bandung terhadap resistensi malation di daerah endemis tinggi, hasilnya nyamuk yang berada di wilayah cimahi, cibeurem dalam kondisi resisten sedang dan tinggi, walaupun Insektisida malation sudah lebih dari 6 tahun tidak digunakan, namun masih mempunyai pengaruh terhadap status kerentanan populasi nyamuk Ae. aegypti di daerah tersebut. Lamanya proses resistensi pada serangga terhadap insektisida sangat bervariasi, dari $1-2$ tahun sampai berpuluh tahun (Georghiou, 1986).

Nyamuk Ae. aegypty yang sudah resisten waktu terpapar oleh insektisida malathion nyamuk relatip tahan, pada saat paparan saat fogging nyamuk hanya pinsan setelah itu beberapa jam bisa hidup kembali, sedangkn hal sebaliknya pada nyamuk yang rentan akan mematikan akibat kehilangan sistem kontrol 
kerja saraf. Transmisi impuls saraf pada nyamuk diperantarai oleh asetilkolin yang bertindak sebagai neurotrnsmitter. Kerja asetilkolin dipengaruhi oleh enzim asetilkolinesterase, yang akan menghidrolisis asetilkolin menjadi kolin dan asam asetat untuk menghentikan impuls saraf (Mulyaningsih, 2003). Peningkatan enzim esterase nonspesifik adalah salah satu proses penting dalam detoksifikasi insektisida, sehingga menyebabkan serangga sasaran menurun status kerentanannya (Yasutomi, 1976).

Setelah dilakukan penelitian menunjukkan, bahwa nyamuk $A e$. aegypti dari kelurahan Neglasari telah mengalami resistensi terhadap insektisida malation. Dengan demikian penggunaan insektisida malation dalam program pengendalian vektor DBD di kelurahan Neglasari di anjurkan untuk merotsi pemakaian insektisida dengan jenis karbamat atau peritroid.

Mekanisme penurunan status kerentanan serangga terhadap insektisida golongan malathion tersebut menunjukkan kesamaan dengan uji yang telah dilakukan oleh Chareonviriyaphap et al., (2003), berkaitan dengan mekanisme resistensi nyamuk An. minimus terhadap insektisida piretroid sintetik yaitu terjadinya perubahan warna menjadi biru apabila terdapat adanya peningkatan enzim monooxygenase. Monooxygenase merupakan rantai enzim yang terkait dengan cytocrome $P-450$ dan peletakan enzim monooxygenase tersebut dapat menunjukkan tingkat toleransi terhadap sintetik piretroid (Nelson $e t$ al., 1996).

Penggunaan insektisida secara terus-menerus cenderung mempercepet proses terjadinya resistensi serangga. Kerentanan serangga tidak hanya dipengaruhi oleh lama dan frekuensi paparan insektisida saja, tetapi juga frekuensi gen yang ada apaakah dominan heterozygote atau homozygote pada populasi serangga (Hemingway et al., 1986a). Faktor genetik lainnya adalah bagiamana interaksi antar gen atau gen-gen pembawa sifat tersebut. Adanya seleksi dari insektisida 
sebelumnya dapat mempengaruhi proses berkembanganya resistensi.

Mekanisme utama kejadian resistensi silang (cross resistance) antara piretroid dengan DDT ditentukan lebih jauh melalui studi lanjut pada tingkat molekuler (Brooke et al., 1999). Hamingway and Ransom (2000), menyatakan bahwa peningkatan enzim monooxigenase terkait dengan toleransi pada insektisida piretroid dalam tubuh nyamuk, meskipun juga terjadi pada lalat rumah (Musca domestica). Menurut Panut Djojosumarto (2008), populasi hama yang sudah resisten terhadap insektisida DDT cenderung resisten terhadap piretroid. Demikian halnya populasi hama yang sudah kebal terhadap insektisida golongan organofosfat cenderung resisten terhadap insektisida karbamat.

\section{Simpulan}

Berdasarkan hasil penelitian yang dilakukan pada bulan September sampai dengan Nopember 2014 di Kecamatan Neglasari Kota Tangerang, maka dapat disimpulkan bahwa nyamuk Ae. aegypti telah mengalami resistensi terhadap insektisida malathion.

Dengan demikian perlu dilakukan monitoring terhadap penggunaan insektisida malathion, dengan memantau efektivitasnya terhadap nyamuk Ae. aegypti di lokasi tersebut

Malathion perlu diganti dengan jenis lain dalam aplikasi thermal fogging, karena nyamuk Ae. aegypti di lokasi tersebut sudah resiten. Sebelum dilakukan thermal fogging dengan insektisida, sebaiknya dilakukan uji hayati nyamuk Ae. aegypti di lokasi tersebut terhadap insektisida yang akan digunakan.

Penelitian lebih lanjut terhadap kelurahan yang belum diteliti, untuk memperoleh gambaran tentang status kerentanan/resistensi secara menyeluruh.

\section{Daftar Pustaka}

Brogdon W.G., R.F Beach., A.M Brber and C.C Rosales. 1992. A Generalyzed Approach to Detection of Organophosphate Resistance in Mosquitoes. 
Medical and Veterinary Entomology 6, 110-114

Brooke. B.D., H.H. Richard, L.K. Lizette, J. Dossou-Yuvo, and C. Maureen. 1999. Evaluation of polymerase chain reaction assay for detection of pyrethroid insecticide resistance in malaria vectors species of An. Gambiae complex. J. Am. Mosq. Contr. Assoc. 15: 565-568

Brown H.W. 1969. Dasar Parasitologi Klinis. Gramedia Jakarta

Candra Budiman. 2007. Pengantar Kesehatan Lingkungan. Penerbit Buku Kedokteran. EGC

Chareonviriyaphap., Rongnoparut P., Chantarumporn P.J., Bang Michael. 2003. Biochemical detection of pyretroid resistance mechanisms in Anopheles minimus in Thailand. Journal of Vector Ecology. 28: 108-116

Christopher S.R. 1960. Aedes aegypti, the yellow fever mosquito. Cambridge Univ Press, London. 307-33

Darwin Akhid. 2008. Status Kerentanan An. Balabacensis dan An. Aconitus Terhadap Insektisida Piretroid Sintetik di Kabupaten Magelang Provinsi Jawa Tengah. Tesis. UGM. Yogyakarta
Djojosumarto Panut. 2008. Pestisida \& Aplikasinya. PT Agromedia Pustaka. Jakarta

Depkes, RI. 2004. Perilaku dan Siklus Hidup Nyamuk Aedes aegypti Sangat Penting Diketahui Dalam Melakukan Kegiatan Pemberantasan Sarang Nyamuk Termasuk Pemantauan Jentik Secara Berkala. Bulletin Harian. Jakarta

Depkes, RI. 2005. Kasus Demam Berdarah Dengue (DBD) di Indonesia. Bulletin Harian. Jakarta

Depkes, RI. 2005. Pemberantasan Nyamuk Penular Demam Berdarah Dengue. Dirjen Pengendalian Penyakit dan Penyehatan Lingkungan. Jakarta

Ffrench-Constant R.H. \& Bonning. B.C. 1989. Rapid mictotitre plate test distinguishes insecticide resistant acetylcholinesterase genotypes in mosquitos Anopheles albomanus, An. Negerrimus and Culex pipiens 3. 9-16

Gandahusada., Ilahude S., Pribadi W. 2006. Parasitologi Kedokteran. Ed.III. Balai Penerbit FKUI. Jakarta

Georghiou, G.P. and R.B. Mellon. 1983. Pesticide Resistence in Time and Space. In: Pest Resistence to Pesticides (Eds. 
G.P. Georghiou \& T. Saito). Plenum Press, New York. P. 146

Georghiou, G.P. 1986. The Magnitude of Resistance Problem. Pesticide Resistance. National Academy Press. Washington

Hamington L.C., Edman J.D and Scott T.W. 2000. Why do Aedes aegypti (Diptera: Culicidae) feed preferentially on human blood. J. Med. Entomol 38:411-422

Hemingway J and C. Smith. 1986a. Field and laboratory Detection of the Altered Acetylcholine esterase Resistance genes Which Confer Organophosphate and Carbamat Resistance in Mosquitoes (Diptera: Culicidae). Bulletin Entomological Research. 76: 559-565

Hemingway J. and H. Ransom. 2000. Insecticide resistance in insect vectors of human disease. Annu. Rev. Entomol. 45: 371391

Hardiyanto, S. 1996. Infeksi Subklinis Mycobacterium leprae dan hubungannya dengan Faktor-faktor Risiko di Indonesia. Kajian Seroepidemiologik dan Imunogenetik. Desertasi. UGM. Yogyakarta
Herath, P. 1997. Insecticides Resistance in Disease Vectors and its Practical Implication. WHO. Geneva

Karunaratne SHP and Hemingway J. 2001. Malathion Resistance and Prevalence of the Malathion Carboxylesterase Mecanism in Population of Mosquito Vector of Disease in Sri Langka. Bulletin of the World Health Organization. 2001; 79(11): 1060 - 1064

Kusbaryanto, Mardihusodo SJ, Tjokrosonto S. 2002. Deteksi resistensi larva Culex quinquefasciatus say terhadap malathion dengan teknik bercak kertas saring di Sleman, Daerah Istimewa Yogyakarta, J.Ked.Yarsi 2002; 10(1): 14 25

Lee, H.L. 1990. A Rapad and Simple Biochemical Method for the Detection of insecticida Resistance Due to Elevate Esterase Activity in Culex quinquefasciatus. Tropical Biomedicine. 7: 21-26

Lee, H.L. 1991. Esterase Activity and Temephos Susceptibility in Aedes aegypti (L) Larvae. Mosquito Borne Disease Bull. 8: 91-94

Mangara S.G., Sukmono., Kusumadiharja J., Suroso T., Sitjipto, H. 2000. The risk of dengue hamorrhagic fever (DHF) outbreak based on 
vector density in kurau, Riau province, Indonesia. Southeast Asian J Trop Med Public Hlth. 31 Suppl 1: 134-9

Mardihusodo, S.J. 1993. Deteksi Dini Resisten Aedes aegypti terhadap malathion dan temefos di Yogyakarta. Lembaga Penelitian Universitas Gadjah Mada. Nomor 14. UGM. Yogyakarta

Mausner and Bahn. 1985. Epidemiology and introductory text, W.B. Saunders Company, Philadelpia

Mulyaningsih Budi. 2004. Keanekaragaman Genetik Aedes albopictus Skuse (Diptera: Culicidae), Vektor Dengue dan Responnya terhadap malation dan temefos, Desertasi. Fakultas Pasca Sarjana. Universitas Gadjah Mada. Yogyakarta

Mulyaningsih Budi. 2003. Penentuan Status Resistensi Larva Aedes albopictus Skuse dari beberapa populasi di Daerah Istimewa Yogyakarta terhadap Insektisida Organofosfat dengan cara mengukur aktivitas Esterase Nonspesifik. Hasil Penelitian. FK. UGM. Yogyakarta

Nelson. D.R., L. Koymans, T. Kamataki, J.J. Stegman, R. Feyereisen, D.J. Waxman, M.R. Waterman, O. Gotoh, M.J. Coon, R.W. Eastbrook,
I.C. Gunsalus, and D.W. Nebert. $\quad$ 1996. P450 superfamily. Update onnew squences. Gene mapping, accession numbers and nomenclature numbers Pharmacogene tics 6: 1-42

Oda T., Igarashi A., Hotta S., Fujita N., Funahara Y., Djakaria S., Hudojo R., Isfarain A., and Djohor D. 1983. Important breeding places: cistern, flower vases earthen jars and tins. Interntional center of Medical Research (ICMR). Annals 3:31-76

Reiter P and Gubler D.J. 1997. Surveillance and control of urban dengue vectors. In Gubler D.J. and Kuno G.(Eds). Dengue and dengue hemorrhagic fever. CAB International. Pp. 425-462.

Reiter P, Amador M.A., Anderson R.A.and Clark G.G. 1995. Short report: dispersal of Aedes aegypti in an rural urban area after blood feeding as demonstrated by rubidiummarked eggs.Am. Soc. Trop. Med. Hyg. 52:177-179

Rezeki S. 2004. Demam Berdarah Dengue. Fakultas Kedokteran Universitas Indonesia. Jakarta

Rhodain and Rosen. 1997. Mosquito vectors and dengue virus-vector relationships. In Gubler D.J. and Kuno G. (Eds) Dengue and dengue hemorrhagic fever. CAB Publication. Pp. 45-60 
Rigau-Perez J.G. and Gubler D.J. 1997. Surveillance for dengue and dengue hemorrhagic fever. In Gubler D.J. and Kuno G.(Eds). Dengue and dengue hemorrhagic fever. CAB International. Pp. 405-423

Rodriguez M.M., Bisset J.A., Mila L.H., Calvo E., Diaz C and Alain Soca L. 1999 Levels of insecticide resistance and its mechanisms in a strain of Aedesaegyptie of Santiago de Cuba. Rev Cubana Med Trop 5:83-88

Rudnick A. 1983. The ecology of the dengue virus complex in Peninsular Malaysia. Proc. Int. Conf. Dengue/Dengue Haemorrhagic Fever. University of Malaysia Press. Kualalumpur, September 1-3, 1983 (pp.7-15)

Rueda L.M. 2004. Zootzxa; Pictorial keys for the identification of mosquitoes

(Diptera:

Culicidae) associated with Dengue Vius Transmission. Magnalia Press. Aucland, New zeland

Seng C.M. and Jute N. 1986. Dengue and dengue hemorrhagic fever outbreak in Lawas Districs, Sarawak, East Malaysia. Med. J. Malaysia. 41:310-319

Sigit, S.H. dan Hadi, U.K. 2006. Hama Pemukiman Indonesia (Pengenalan, Biologi dan Pengendalian). Unit Kajian
Pengendalian Hama

Pemukiman. Fakultas

Kedokteran Hewan. Institut Pertanian Bogor

Small, G. 1998. Genetical background of insecticide resistance, Paper Molecular Entomology Workshop, Center for Tropical Medicine Gadjah Mada University. Yogyakarta

Smith C.G.E. 1956. The History of dengue in tropical Asia and its probable relationship to the mosquito Aedes aegypti. J. Trop. Med. Hyg. 59:3-8

Sucipto, Cecep Dani, 2011, Vektor Penyakit Tropis, Gossyen Publishing, Yogyakarta

Sudijono. 1983. Malathion. Ditjen P3M Depkes RI. Jakarta

Sungkar, S. 2005. Bionomk Aedes aegypti, vector Demam Berdarah Dengue. Majalah Kesehatan Indonesia 55 (4): 384-389

Suroso T. 2000. Development of DHF control policy in Indonesia from 1968 to 2000. Depkes RI. Jakarta

Sutaryo. 2004. Dengue. Medika, Fakultas Kedokteran, Universitas Gadjah Mada Yogyakarta

WHO. 1975. Manual on Practical Entomology in Malaria. Part II. 
Methods and techniques. WHO. Geneva

WHO. Expert Committee on Vector Biology and Control. 1980. Resistance of Vectors of Diseases to Pesticides. WHO Technical Report Series. No.665. WHO. Geneva 82p

WHO. 1983. Integrated vector control. WHO, Geneva

WHO. 1986. Dengue haemorrhagic fever, diagnosis, treatment and control. WHO Geneva

WHO. 1986. Resistence of vectors and reservoirs of desease to pesticides. WHO Tech Rep Ser 737. WHO. Geneva

WHO Expert Comité on Vector Biology and Control. 1992. Vector Resistance to Pesticide. WHO Technical Report Series. No. 818. WHO. Geneva. 62p

WHO Studi Group. 1995. Vector Control for Malaria and Other Mosquito Borne Diseases. WHO Technical Report Series. No. 857. WHO. Geneva. $91 \mathrm{p}$

WHO. 2006. Pesticides and Their Application: For the Control of Vectors and Pests of Public Health Importance. WHO/CDS/NTD/WHOPES/G CDPP / 2006.1

Widiarti., Boewono D.T., Widyastuti U., Mujiono. 2004. Uji biokimia kerentanan vector malaria terhadap insektisida organofosfat dan karbamat di propinsi Jawa Tengah dan Daerah Istimewa Yogyakarta

Yasutomi. K. 1976. Role of detoxication esterase in insecticide resistences in G.P. Georghiou \& T. Saiti (ed): Pest Resistance to pesticide. Plenum Press. New York 